\title{
Botanical composition of sheep diet in two contrasting environments at Tierra del Fuego steppe (Argentina)
}

\begin{abstract}
The botanical composition of the diet of sheep in two contrasting environments of the fueguian steppe was compared by means of a microscopic analysis of feces, during the spring and summer 2006. In both areas of study, grasses showed to be the most important group in the diet of both locations and of both seasons, followed by native dicotyledonous. In addition, it was found that in the abandoned pasture of Cullen ranch, the intake of Hieracium pilosella, an invasive species, is high. Management strategies should be targeted to the conservation of grasses which are the life forms that are most susceptible to over grazing disturbance. Besides, these results contribute to the stage of advancement of the invasive species H. pilosella in the fueguian steppe and to the knowledge of the incorporation of this species in the diet of livestock, and possibly in the diets of native herbivores.
\end{abstract}

Keywords: herbivory, diet selection, sheep, fueguian steppe
Volume 2 Issue 4 - 2018

\author{
Fernández Pepi MG,' Arriaga MO, ${ }^{2}$ \\ Stampacchio $\mathrm{ML}^{2}$ Collantes $\mathrm{MB}^{3}$ \\ 'Departamento de Producción Animal, Universidad de Buenos \\ Aires (FAUBA), Argentina \\ 'Laboratorio de Anatomía Vegetal, Museo Argentino de Ciencias \\ Naturales Bernadino Rivadavia, Argentina \\ ${ }^{3}$ Laboratorio de Ecología de Pastizales, Museo Argentino de \\ Ciencias Naturales Bernadino Rivadavia, Argentina
}

Correspondence: Fernández Pepi, Departamento de Producción Animal, Universidad de Buenos Aires, Facultad de Agronomía (FAUBA), Av San Martín 4453 (CI4I7DSE), Ciudad Autónoma de Buenos Aires, Argentina, Email fernandezpepi@agro.uba.ar

Received: June 13, 2018 | Published: July II, 2018

\section{Introduction}

The relationship between plant's features and different disturbances has received great attention ${ }^{1,2}$ mainly due to changes in plant species richness and composition associated with overgrazing. ${ }^{3}$ It has been shown that species with different traits often respond differently to grazing, but the emerging patterns tend to vary among studies..$^{4-11}$ Pasturing by cattle frequently brings about changes in the structure and the operation of the natural pastures, affecting key processes such as the primary and secondary productivity, changes in the vegetation, cycle of nutrients. ${ }^{12,13}$ botanical composition changes are among the most remarkable modifications observed in pastures as a consequence of the replacement of palatable by non- palatable species., ${ }^{4-18}$ Selective herbivory is a dominant mechanism, as species consumed less frequently or intensively have a competitive advantage as they substitute those species consumed more severely. ${ }^{19-21}$ In addition, soil tilling associated with the implantation of pastures and other methods may facilitate the colonization of exotic weeds. ${ }^{22-24}$ The presence of weeds usually reduces the amount and quality of available fodder, increases the handling costs and may harm animal responses. ${ }^{25}$ The introduction of domestic animals in the Patagonia region, primarily ovine cattle occurred at the beginning of the last century when the early settlers handled the natural grasslands applying experiences gained in different ecosystems. ${ }^{26}$ This management brought about deep changes to the soil and flora composition. ${ }^{27-29}$ Invasion of Hieracium pilosella L. (Asteraceae) in the Austral Patagonia ${ }^{30,31}$ is a successful invasive species $^{32,33,34}$ associated to overgrazing since it is highly competitive spreading rapidly by means of vegetative growth of stolons and rhizomes and through mono-specific feeding patches formations. Its greatest economic impact is the decrease of primary and secondary productivity caused by the replacement of native and palatable species in the original grasslands. ${ }^{36-39}$ In the province of "Tierra del Fuego" (Argentina) the current invaded area is also overcome by fescue grasslands (Festuca gracillima, Hooker f.) and "Mata Negra" shrub (Chiliotrichum diffusum, Forster f.; O. Kunze;). ${ }^{31,40}$ At present, the invasion of $H$. pilosela is wide-ranging in the step region, where it commonly replaces native species from the inter-coironal or the interspaces between bushes. These locations are occupied naturally by a large number of little native grasses and naturalized species which represent a key contribution to diversity and to the pastoral value of that community. The knowledge of the botanical composition of the herbivorous diets is necessary in order to be able to decide over land handling alternatives. Our purpose was to compare sheep diets in two areas of the Fueguian steppe: a natural grassland (Maria Behety ranch: $\mathrm{MB}$ ) and an old pasture (Cullen ranch: EC), taking into account the modification of vegetal communities brought about by different managements handlings.

\section{Materials and methods}

\section{Study area}

The study was conducted in two branches located in the Fueguian steppe. Maria Behety ranch (MB) is placed $15 \mathrm{~km}$ northwest from the

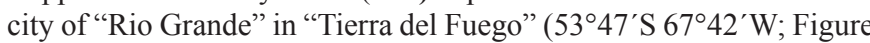
1). The climate varies from semi-arid to sub-humid with oceanic features. ${ }^{41}$ The average annual rainfall is $371 \mathrm{~mm}$ with a deficiency in the ground available water between November and mid-April. The dominant vegetation are Coiron grasslands (Festuca gracillima), with areas dominated by Chilotrichum difussun and Empetrum rubrum. In the low-lying areas there are meadows containing hydrophytic vegetation. ${ }^{42}$

Cullen ranch (EC) is located north from the Fueguian steppe (52 $55^{\prime}$ ' S, 68³3' W; Figure 1). It has a pastureland (c.a. 1220 ha), containing an area which has been used with pastures for 30 years, actually covered with Hieracium pilosella (above 15\%;45).The mean 
annual rainfall (over the last 100 years) measured close to the ranch's minor is $335 \mathrm{~mm}$, and the month's average temperature during the coldest month is $0^{\circ} \mathrm{C}$ and reaches $10^{\circ} \mathrm{C}$ in the warmest month. Since this area is a wavy relief, it has canyons that limit to low and humid plains ("Vegas") with abundant herbaceous vegetation composed of different species of grasses (Festuca spp., Poa spp., Bromus spp., Agrostis spp.), Forbs (Taraxacum officinale, Caltha sagittata), sedges (Carex spp.) and rushes (Juncus spp. and Luzula spp.). The highlands were covered generally by the plant species "Coirón" (Festuca gracillima), Chiliotrichum difussum and "Murtilla" (Empetrum rubrum). ${ }^{43}$

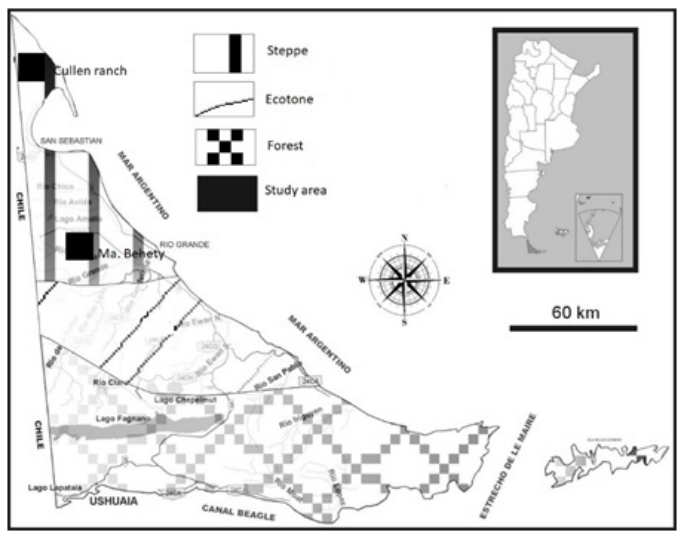

Figure I Natural environments of the Tierra del Fuego province: steppe, ecotone and forests. In the steppe is where the study areas are located: MB, MaríaBehety Ranch; EC, Cullen Ranch.

\section{Floristic data}

To determine the floral and diets compositions, plants of the present communities and sheep faeces were collected during the spring and the summer of 2006 at both locations. The plants which were collected were identified using the reference flora. ${ }^{44-46}$ Species were grouped according to their life forms into 8 categories: (sensu 51): cushion (CU), dwarf shrub (DS), tall shrub (TS), grasses (GR), native herb dicotyledons (ND), exotic herb dicotyledons (ED), introduced herb dicotyledons to improvee grasslands (ID), graminoids (GRA).

\section{Sampling and treatment of feces}

Food habits of sheep were studied during spring and summer by randomly collecting 1-5 to dung units of every dropping at each feeding area. Faeces samples were spread over paper and dried at ambient temperature for several days and then put into paper bags. Later on, the grounded samples were boiled with $5 \% \mathrm{NaOH}$ for $1-2$ minutes and then rinsed with $\mathrm{NaClO}$, bleached for a few minutes, and thoroughly rinsed in water again. Three slides were made from each sample for microscopic observation, 9 preparations were made per stay, for each station sampled, and 20 optical fields were quantified for each one.

\section{Data Analysis}

The floristic composition of a sheep's diet can be recognized by the relative frequencies of species infaecal samples by means of a microscopic recognition of the epidermis with their cuticle ${ }^{47}$ and classified by forms of life, location, and season of the year. Plants were identified at species level, but genus or other taxonomic categories were used too when possible. The diversity of plant species in the diet was estimated by the Shannon Diversity Index $(\mathrm{H}),{ }^{48}$ and the species similarity in the diets between seasons and locations by the Sorensen index (SI). ${ }^{49}$ Diet composition within and among communities and seasons was studied by principal component analysis (expressing every species consumption as proportion of the total of species consumed). Analyses were performed using the program PAST. ${ }^{50}$

\section{Applied formulas}

\section{i. Shannon-Wiener Diversity Index $(\mathrm{H}): \mathrm{H}=-\Sigma \mathrm{Pi} * \ln \mathrm{Pi}$}

Where $\mathrm{Pi}=$ relative abundance and $\mathrm{ln}=$ natural logarithm.

\section{ii. Sørensen's Index(SI): $\mathrm{SI}=(2 \times \mathrm{C}) /(\mathrm{Gi}+\mathrm{Si})$}

Where $\mathrm{C}=$ number of common species between $\mathrm{Gi}$ and $\mathrm{Si}$ diets; $\mathrm{Gi}=$ number of species in the diet of geese, and $\mathrm{Si}=$ number of species in sheep diet. The values as $(0-0.25)$ indicate low similarity, $(0.26-$ $0.50)$ moderate similarity, (0.51-0.75) high similarity and (0-76-1) full similarity.

\section{Results}

There was a great similarity in botanical dietary composition between periods studied in EC and MB. While comparing the SI taking into account the same period in between sites, the spring period is the most similar in floristic composition (Table 1). The most significant differences were noticed in the frequency of ingestion of some species of grasses, native herbaceous dicotyledons, exotic herbaceous dicotyledons, herbaceous dicotyledons invader and sedges and rushes, being the two first, the most frequently consumed. The diversity and the evenness of the diet tend to be greater during two periods EC, which corresponds to modified pasture (Table 2). The values of these indices show significant differences in $M B$ throughout the summer period compared to $\mathrm{MB}$ during spring, and $\mathrm{EC}$ in both periods ( $\mathrm{p} \cdot 0.005)$, having $\mathrm{MB}$ in summer the least diverse composition (Table 2).

Table I Sörensen's Index values calculated to compare the similarity in the floristic composition of the diets. The values are interpreted following as (0$0.25)$ indicate low similarity, $(0.26-0.50)$ moderate similarity, $(0.5 \mathrm{I}-0.75)$ high similarity and (0-76-I) full similarity

\begin{tabular}{lll}
\hline & MB-SU & EC-SP \\
\hline MB-SP & 0.39 & 0.76 \\
EC-SU & 0.52 & 0.83
\end{tabular}

MB, Ma Behety; EC, Cullen; SU, summer; SP, spring

Table 2 Diversity index $(\mathrm{H})$ (Average and error values) of sheep's diets, during spring and summer, in both studies areas

\begin{tabular}{lllll}
\hline & MB-Nov & MB-Feb & EC-Nov & EC-Feb \\
\hline$H$ & $3.30 \pm 0.19$ & $2.70 \pm 0.28$ & $3.79 \pm 0.18$ & $3.33 \pm 0.31$ \\
\hline
\end{tabular}

MB, Ma. Behety; EC, Cullen; SU, summer; SP, spring

In the area corresponding to the old pasture (EC), the life forms consumed in both periods were GR, ND, GRA and ED, being the frequency of consumption of GR the highest in both periods. The other three life forms showed significant differences, though ND showed the highest in spring and the other two in summer (Figure 2). Whereas the species in GR category with significant differences were: Agrostis sp., Elymus sp., Festuca sp., Poa sp., being the three first more frequently preferred by sheep in summer, while Poa sp. was in the spring period. The form life ND with significant differences: Acaena sp., which is more common in the summer intake, as Valeriana sedifolia is. The $\mathrm{ED}$, Hieracium pilosella, is consumed more frequently during the 
summer in EC. Of the GRA, Carex sp. is the species which differs more significantly, being more consumed during summer. In the natural pasture $(\mathrm{MB})$, the life forms which are most commonly consumed are GR (50\%), followed in importance by ND (23\%), GRA $(21 \%)$, considering the spring period. During the summer, the most consumed life form remains to be GRA $(62 \%)$, followed in frequency of intake by GRA(17\%), TS (12\%) and in a lesser proportion ND $(6 \%)$ (Figure 2). Comparing the two periods, we observe an increase in the intake of GRA and a decrease in the consumption of ND, which is accompanied by an increase in the frequency of consumption of woody plants (Figure 2). Within the GRA, the species most commonly consumed in the spring period is Poa sp., Elymus sp. next in importance. Deschampsia sp. has a frequency of intake of $1.7 \%$. During the summer, Poa sp. and Festuca sp. are the most consumed, by a $22 \%$ and $29 \%$ respectively. Chilliotrichum sp. is more consumed in summer, compared to their intake during the spring. Since Cullen is an abandoned pasture in Ma Behety the frequency of intake of the invasive species (Hieracium) is low or null. In the summer period there is also a difference in the frequency of intake of GR, SR and TS, which is higher in MB. Taking into account the analysis of the principal components, 1 and 2 ( $75 \%$ of total variability), the diet of the sheep in EC during spring is differentiated from the rest of the diets, primarily because of the frequency in the intake of Phleum sp. y Cerastium sp. (Figure 3). The diets of summer in CU and in MB during both periods may be differentiated taking into consideration location and period, by the frequency of Festuca sp., Olsynium sp. and Chilliotrichum diffusum in take in the case of MB throughout all summer; while the same location during spring is characterized by the frequency of the intake of Carex sp. y Juncus sp.; and EC during the summer taking into account the Hiercium pilosella and Elymus agropyroides in take (Figure 3 ).

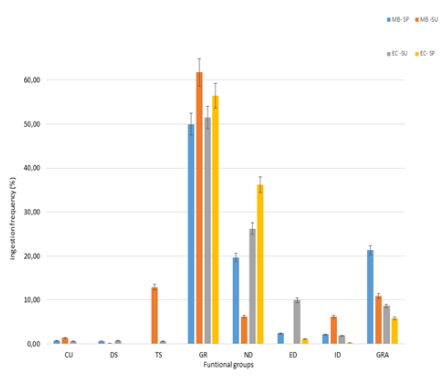

Figure 2 Frequency of the intake of different life forms, taking into account the ranch and period of time analyzed: CU, cushion; DS, dwarfshrub; TS, tallshrub; GR, grasses; ND, nativeherb dicotyledons; ED, exoticherb dicotyledons; ID, introducedherb dicotyledons to improve grasslands; GRA, graminoids; MB: Ma. Behety, EC: Cullen, SU: summer, SP: spring.

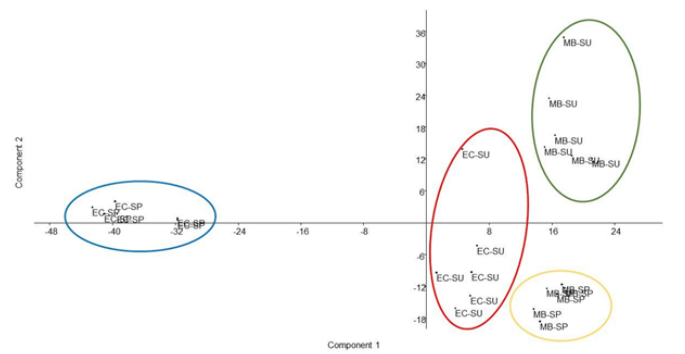

Figure 3 Main components analysis that allow to differentiate both areas in the sampled periods, for components I and 2 (75 per cent out of the total variability). MB, Ma. Behety; EC, Cullen; SU, summer; SP, spring.

\section{Discussion}

Differences found among diets not only reflect food offer but also may be associated to environmental conditions, location within the land and phenologic conditions of the plant species, all which may show the habitat use of sheep.

Other studies conducted throughout the continental extraandine Patagonia, in the steppe and in the Fueguian ecotone, describe similar changes also brought about overgrazing, ${ }^{51-55}$ as well as a selectivity of diets associated to the location of the field and to the availability according to the ambient features regarding seasonality. ${ }^{56} \mathrm{It}$ is common knowledge that associated to traditional handling; the formation of new habitats is brought about because of the action of sheep, which have increased the landscape's diversity. Some of these habitats, such as the grasslands, the coironals and the open scrublands have improved their vitality and the chance to forage; while the Diddledee species have worsen it. ${ }^{57}$ The temperate semi-arid grasslands located in the central part of Argentina have a history of about 100 years of being grazed by sheep and cattle. In uplands, compositional changes associated with grazing include the replacement of palatable midgrasses for palatable shortgrasses ${ }^{58,59}$ However, under conditions of long-term, heavy grazing, the palatable grasses commonly give way to an increase cover or even to an invasion by unpalatable grasses. ${ }^{60}$ The results presented by this study concur with what has been described by those authors, given that in the diet it was identified the intake of an invasive species, as Hieracium pilosella, whose presence is stronger in EC, an abandoned pasture where the species is taking over space.Herbivory influenced total vegetation cover but not species composition of plants colonising disturbed plots. This is reflected in the composition of the communities and of the studied diets.

\section{Conclusion}

This knowledge constitutes a basis for management and conservation of these natural grasslands in the Fueguian steppe. Management strategies should be targeted to the conservation of grasses which is the life form most susceptible to overgraze and cause disturbance. In addition, these results contribute to the state of progress of the invasive species Hieracium pilosella in the Fueguian steppe and to the knowledge of the incorporation of this species in the diet of livestock, and possibly in that of native herbivores. ${ }^{61-63}$

\section{Acknowledgments}

We are in debt to Dr. J. Anchorena and Lic. C. Escartín for field assistance during the collection of material; to Mrs. María Dolores Montero for her collaboration in handling herbarium material; Estancia María Behety and Estancia Cullen to their owners and administrators, for their kindness.

\section{Conflict of interests}

Author declares that there is no conflict of interest.

\section{References}

1. Lavorel S, McIntyre S, Landsberg J, et al. Plant functional classifications: from general groups to specific groups based on response to disturbance. Trends in Ecology and Evolution. 1997;12(12):474-478.

2. Smith TM, Shugart HH, Woodward FI, editors. Plant functional types: their relevance to ecosystem properties and global change. Cambridge University Press, Cambridge, UK; 1997. 
3. Bakker JP. The impact of grazing to plant communities. In: Wallis De Vries MF, Bakker JP, editors. Grazing and conservation management. Kluwer, Dordrecht, Netherlands; 1998. p. 137-184.

4. Noy-Meir I, Walker NB. Stability and resilience in rangelands. In: PJ Joss, PW Linch, editors. Rangelands: a resource under siege. Australian Acemic of Science, Canberra, Australia; 1989. 21 p.

5. McIntyre S, Lavorel S, Tremont RM. Plant life-history attributes: their relationship to disturbance response in herbaceous vegetation. Journal of Ecology. 1995;83(1):31-44.

6. McIntyre S, Lavorel S, Landsberg J. et al. Disturbance response in vegetation-towards a global persperctive on functional traits. Journal of Vegetation Sciencie. 1999;10(5):621-630.

7. Sternmberg M, Gutman M, Perevolostky A, et al. Vegetation response to grazing management in a Mediterranean herbaceous community: a funcional group approach. Journal of Applied Ecology. 2000;37(2):224-237.

8. Bullock JM, Franklin J, Stevenson MJ, et al. A plant trait analysis of responses to grazing in a long-term experiment. Journal of Applied Ecology. 2001;38(2):253-267.

9. Diaz S, Noy-Meir I, Cabido M. Can grazing response of herbaceous plants be predicted from simple vegetative traits. Journal of Applied Ecology. 200;38(3):497-508.

10. Dupré C, Diekmann M. Differences in species richness and life history traits between grazed and abandoned grasslands in southern Sweden. Ecography. 2001;24(3):275-286.

11. McIntyre S, Lavorel S. Livestock grazing in subtropical pastures: steps in the analysis of attribute response and plant functional types. Journal of Ecology. 2001;89(2):209-226.

12. Whicker A, Detling J. Ecological consequences of prairie dog disturbance: Prairie dogs alter grassland patch structure, nutrient cycling, and feedingsite selection by other herbivores. Bioscience. 1988;38(11):778-785.

13. Milton SJ, Hoffman MT. A conceptual model of arid rangeland degradation. Bioscience.1994;44(2):70-76.

14. Archer S. Have Southern Texas savannas been converted to woodlands in recent history? Am Nat. 1989;134(4):545-561.

15. Archer S. Woody plant encroachment into south western grasslands and savannas: Rates, patterns and proximate causes. In: Vavra M, Laycock W, editors. Ecological Implications of Livestock herbivory in the west. Society for Range Management, Denver CO, USA; 1992. 13 p.

16. Hobbs RJ, Hopkins AJ. From frontier to fragments: European impact On Australia vegetation. In: Saunders DA, Hopkins AJ, editors. Australia Ecosystems: 200 years of Utilizations, Degradation and Reconstruction. Procceedings of the Ecological Society of Australia; 1990. 93 p.

17. Westoby M, Walker B, Noy-Meir I. Opportunistic management for rangelands not at equilibrium. J Range Manag. 1989;42(4):266-274.

18. Machines DG, Lauenroth WK. Quantitative effects of grazing on vegetation and soils over a global range of environments. Ecol Monogr. 1993;63(4):327-366.

19. Anderson VJ, Briske DD. Herbivore-induced species replacement in grasslands: is it driven by herbivory tolerance or avoidance? Ecol Appl. 1995;5(4):1014-1024.

20. Briske DD. Developmental morphology and physiology of grasses. In Heitschmidt RK, Stuth JW, editors. Grazing management an ecological perspective. Timber Press; 1991. p. 85-108.

21. Briske DD, Richards JH. Physiological responses of individual plants to grazing: current status and ecological significance. In: Vavra M, Laycock
WA, editors. Ecological implications of livestock herbivory in the West. Society for range Management; 1994. p.147-176.

22. Hobbs RJ, Huenekke LF. Disturbance, diversity and invasion: implication for conservation. Conservation Biology. 1992;6(3):324-337.

23. Davis MA, Grime JP, Thompson K. Fluctuating resources in plant communities: a general theory of invasibility. Journal of Ecology. 2000;88(3):528-534.

24. Walker S,Wilson JB, LeeWG. Does fluctuating resource availability increase invasibility? Evidence from field experiments in New Zealand short tussock grassland. Biological Invasions. 2005;7(2):195-211.

25. Ditomaso JM. Invasive weeds in rangelands: species, impacts, and management. Weed Science. 2000;48(2):255-265.

26. Paruelo JM, Bertiller MB, Schlichter TM, et al. Secuencias de deterioro en distintos ambientes patagónicos. Su caracterización mediante el modelo de estados y transiciones. Convenio Argentino Alemán. Cooperación Técnica INTA-GTZ; 1993. 110 p.

27. León RJC, Aguiar MR. El deterioro por uso pasturil en estepas herbáceas patagónicas. Phytocoencolgía. 1985;13:181-196.

28. Perelman SB, León RCJ, Bussacca JP. Floristic changes related to grazing intensity in a Patagonia shrub steppe. Ecography. 1997;20(4):400-406.

29. García Martinez GC. Cambios edáficos asociados al pastoreo ovino en la estepa patagónica. Distrito Occidental, Facultad de Agronomía, Universidad de Buenos Aires (UBA); 2005. 37 p.

30. Domínguez E. Plantas exóticas presentes en el Parque Nacional Pali Aike, XII Región, Chile. Chloris Chilensis. 2004;7(2).

31. Livraghi E, Cabeza S, Kofalt R. Documento de trabajo sobre Hieracium pilosella L. Informe Técnico INTA; 1998.

32. Allan HH. Notes of the occurrence of certain exotic plants in New Zealand New Zealand Journal of Agriculture. 1924;29:311-315.

33. Voss EG, Böhlke MW. The status of certain hawkweeds (Hieracium subgenus Pilosella) in Michigan. The Michigan Botanist. 1978;17:35-47.

34. Winkler E, Stöcklin J. Sexual and vegetative reproduction of Hieracium pilosella $\mathrm{L}$. under competition and disturbance: A grid-based simulation model. Annals of Botany. 2002;89(5):525-536.

35. Moen J, Meurk CD. Competitive abilities of three indigenous New Zealand plant species in relation to the introduced plant Hieracium pilosella. Basic and Applied Ecology. 2001;2(3):243-250.

36. Makepeace W. Growth, reproduction, and production biology of mouseear and king devil hawkweed in eastern South Island, New Zealand. New Zealand Journal of Botany. 1985;23(1):65-78.

37. Makepeace W, Dobson AT, Scott D. Interference phenomena due to mouse-ear and king-devil hawkweed. New Zealand Journal of Botany. 1985;23(1):79-90.

38. Treskonova M. Changes in the structure of tall tussock grasslands and infestation by specie of Hieracium in the Mackenzie country, New Zealand. New Zealand Journal of Ecology. 1991;15(1):65-78.

39. Johnstone PD, Wilson JB, BremnerAG. Change in Hieracium populations in Eastern Otago over the period 1982-1992. New Zealand Journal of Ecology. 1999;23(1):31-38.

40. Cipriotti PA, Rauber RB, Collantes MB, et al. Hieracium pilosella invasion in the Tierra del Fuego steppe, Southern Patagonia. Biological Invasions. 2010;12(8):2523-2535.

41. Walter H, Box EO. Climate of Patagonia. In: West NE, editor. Temperate deserts and Semi-deserts. Elsevier, Amsterdam;1983. p. 432-435. 
42. Posse G, Livraghi E. Dieta de la llama (Lama glama) en la estepea magallánica. Ecología Austral. 1997;7(1):42-46.

43. Koremblit G, Forte Lay JA. Características agrohidrolócias del norte de Tierra del Fuego. VII Congreso Argentino de Meteorología. 1996. p. 85-86.

44. Correa M. Flora Patagónica. Parte III, Gramineae. Colección Científica INTA; $1978.94 \mathrm{p}$.

45. Moore DM. Flora of Tierra del Fuego. Missouri Botanical Garden, USA; 1983.

46. Zuloaga FO, Morrone O, Belgrano M, editors. Catálogo de plantas vasculares del Cono Sur (Argentina, Surde Brasil, Chile, Paraguay y Uruguay). Monogr Syst Bot Missouri Bot Gard. 2008;107:1-983.

47. Arriaga MO. Metodología adaptada al estudio de hábitos alimentarios en insectos. Comunicaciones de Museo Argentino de Ciencias Naturales "Bernardino Rivadavia" e Instituto Nacional de Investigaciones de las Ciencias Naturales; 1986. p. 103-111.

48. Hurtubia J. Trophic diversity measurement in sympatric predatory species. Ecology. 1973;54(4):885-890.

49. Sorensen T. A method for establishing groups of equal amplitude in plant sociology based on similarity of species content. Biol Skr. 1948;5(4):1-34.

50. Hammer O, Harper DAT, Ryan PD. PAST - Palaeontological S Tatistics. 2007. 86 p.

51. Boelcke O, Moore DM, Roig FA, editors. Transecta Botánica de la Patagonia Austral. CONICET (Argentina), Royal Society (UK) \& Instituto de la Patagonia, Chile; 1985.

52. Cingolani A, Posse G, Collantes MB. Plant functional traits, herbivore selectivity and response to sheep grazing in Tierra del Fuego steppes (Patagonia, Argentina). Journal of Applied Ecology. 2005;42(1):50-59.

53. Collantes MB, Anchorena J, Cingolani AM. The steppes of Tierra del Fuego: floristic and growth-form patterns controlled by soil fertility and moisture. Plant Ecology. 1999;140(1):61-75.
54. León RJC, Bran D, Collantes M, et al. Grandes unidades de vegetación de la Patagonia extra-andina. Ecología Austral. 1998;8:125-144.

55. Fernández Pepi MG, Arriaga MO, Alvarenga EC, et al. Comparación de la dieta de guanacos y vacas según los recursos en el ecotono de Tierra del Fuego. Rev Arg Prod Animal. 2014;34(1):1-7.

56. Posse G, Anchorena J, Collantes MB. Seasonal diets of sheep in the steppe region of Tierra del Fuego, Argentina. J Range Manage. 1996;49(1):24-30.

57. Anchorena J, Cingolani AM, Livraghi E, et al. Manejo del pastoreo de ovejas en Tierra del Fuego. EDIPUBLI SA, Buenos Aires, Argentina; 2001.

58. Llorens EM. Viewpoint: The state and transition modelapplied to the herbaceous layer of Argentina's calden forest. $J$ Range Manage. 1995;48(5):442-447.

59. Distel R, Bóo R. Vegetation states and transitions in temperate semiarid rangeland of Argentina. In: West N, editor. Proceedings of the Fifth International Rangeland Congress. Salt Lake City, Utah, USA; 1996.

60. Moretto AS, Distel RA. Competitive interactions between palatable and unpalatable grasses native to a temperate semi-arid grassland of Argentina. Plant Ecology. 1997;130(2):155-161.

61. Cipriotti PA, Rauber RB, Collantes MB, et al. Control measures for a recent invasion of Hieracium pilosella in Southern Patagonian rangelands. Weed Research. 2012;52(1):98-105.

62. Cassola AG, Latour MC, Pereyra JA, Serra J. Relevamiento de la vegetación. In Relevamiento expeditivo de los recursos naturales de la zona cordillerana de la region Patagónica: Informe técnico. Vallerini JA, Cohen LE, editors. Arg, Instituto Nacional de Tecnología Agropecuaria, Consejo Federal de Inversiones; 1975. 185 p.

63. Cabido M, Parra MJ. Vegetación y flora de la Reserva Natural Chancaní. Agencia Córdoba Ambiente. Gobierno de la Provincia de Córdoba, Córdoba. 2002. 